\title{
THE ROLE OF PUBLIC AGRICULTURAL RESEARCH IN THE LOCAL WINE PRODUCTION SYSTEM IN THE VALLEY OF SÃO FRANCISCO
}

\author{
Samuel Carvalho de Azevedo Marques ${ }^{a}$ \\ a Senai Cimatec University Center, Orlando Gomes Avenue, 1845 - Piatã, Salvador, \\ BA, 41650-010, Brazil.samuelcmarques@gmail.com
}

\begin{abstract}
Agricultural research is a key element for the development of agribusiness. Research organizations support productivity in the agricultural sector. This work aims to situate the role of the Brazilian Agricultural Research Corporation in the wine industry in the São Francisco Valley, Northeast Brazil. The studies selected based on a literature review treat of public agricultural research organizations. The articles found in the ScienceDirect and Portal da Capes databases were selected according to eligibility criteria. The data and results indicated that this type of organization has a prominent role in the agricultural sector. From this, it is concluded that agricultural research if absorbed by agribusiness can be an important source of innovation in local wine production.
\end{abstract}

Keywords: Research organizations; EMBRAPA; Wine production; São Francisco Valley.

\section{O PAPEL DA PESQUISA PÚBLICA AGROPECUÁRIA NO SISTEMA LOCAL DE PRODUÇÃO DE VINHOS NO VALE DE SÃO FRANCISCO}

Resumo: A pesquisa agropecuária é um elemento chave para o desenvolvimento do agronegócio. Organizações de pesquisa apoiam a produtividade no setor agrícola. Este trabalho tem como objetivo situar o papel da Empresa Brasileira de Pesquisa Agropecuária na indústria do vinho no Vale do São Francisco, Nordeste do Brasil. Os estudos selecionados com base em revisão da literatura tratam de organizações públicas de pesquisa agrícola. Os artigos encontrados nas bases de dados ScienceDirect e Portal da Capes foram selecionados de acordo com critérios de elegibilidade. Os dados e resultados indicaram que esse tipo de organização tem papel de destaque no setor agrícola. A partir disso, conclui-se que a pesquisa agropecuária se absorvida pelo agronegócio pode ser uma importante fonte de inovação na produção vinícola local.

Palavras-chave: Organizações de pesquisa; EMBRAPA; Produção de vinho; Vale do São Francisco. 


\section{INTRODUCTION}

The first introduction of grapevines in Brazil was made by Portuguese colonists in 1532, through Martin Afonso de Souza, in the then Captaincy of São Vicente, today the State of São Paulo. In the State of Rio Grande do Sul, the cultivation of wine varieties was encouraged through government stimuli.

Grape production reached 1.5 million tons / year. With about $50 \%$ it is destined for processing, for the production of wines, juices and other derivatives, and $50 \%$ marketed as table grapes. Of the total industrialized products, $42 \%$ are table wines and $49 \%$ are grape juices, About $7 \%$ are fine wines. [1]

Brazilian tropical viticulture was effectively developed in the 1960s, with the planting of commercial table grape vineyards in the São Francisco River Valley region, in the Brazilian semi-arid northeast. [2]. Currently, the São Francisco valley region is considered the main tropical wine region in Brazil and Brazil is at the forefront of research on tropical wines.

According to Berger [3] Embrapa, a Brazilian public agricultural research company, has a fundamental role in the agribusiness segment through research and its dissemination, contributing to the implementation of new technologies, through its products, processes, technological assets and services. The company is part of the National Agriculture Innovation System.

According to Mendes [4] "the approach of the National Agricultural Research System has as its central axis the articulation for the generation of knowledge." The Information and Knowledge Agriculture System goes beyond generation and focuses on the dissemination of knowledge. In turn, the Innovation System in Agriculture "integrates the generation, diffusion and use of knowledge"

Embrapa identified as a component of the system is part of the network [5] of collaborations in the agro-industrial productive environment. Acting as a source of information, generation and dissemination of knowledge for innovation in the system. The interaction with the agricultural industry is a routine of the company in processes of generation, accumulation, use and diffusion of knowledge and innovations $[6,7,8]$. These interactions occur in the grape and wine sector traditionally in several wine regions in Rio Grande do Sul and more recently in northeastern Brazil, in the São Francisco Valley, Brazilian semiarid $[9,10]$.

This study considers the importance of agribusiness and agribusiness in Brazil and in the world [11,12], either due to the natural resources involved in food production or the importance of this sector for the Brazilian and regional economy [13]. The sector has an impact on job creation, income generation for families; and on social development and sustainability. In this sense, the incorporation of more modern and innovative technologies in agro-industrial activities is a current challenge.

\subsection{Agricultural innovation in local wine production systems}

Embrapa Semiárido [14] as other research units of the company interacts with agribusiness companies and producers in Brazil and in the São Francisco Valley. This interaction disseminates technological solutions created in each different local 
production system in the country. Research works deal with clusters or Local Production Systems (SLP) in Brazil, as studies and research by Suzigan [15]. The author presents methodology for the identification and delimitation of SLPs. What was relevant to study the proposed region and place the study in current literature. The elements of the local production system discussed in the literature apply to regions defined as a zone of wine production.

According to Suzigan [16], a cluster or SLP refers to a geographic agglomeration of a large number of companies of different sizes, with the presence of small companies, manufacturers of a type of product or similar products and their respective suppliers and service providers. There are several possible configurations for this phenomenon and some form of public or private governance, or some form of coordination, prevails. The agents involved [companies, institutions, research centers] have "geographical proximity", which would be essential for the coordination and "dissemination of new knowledge".

When these systems include public or private institutions focused on education, training, research, engineering and financing, they are configured as Local Productive and Innovative Systems. According to Lastres and Cassiolato [17] these territorial systems involve learning, supply relations, services, trade, representation of interests and association. They would be clusters of economic, political and social agents involving producers of goods and services, inputs and equipment.

In the Embrapa system, there is research in agriculture that involves the production of knowledge [18]; intermediate actors facilitating the process of transferring knowledge and technologies between the segments; agribusiness organizations in the value chain that take advantage of RD\&l results [19] and also produce their own independent innovations.

Schumpeter presented a perspective of "inclusion of the State in the list of agents of technological innovation" referring "specifically to the United States, whose agrarian economy was repeatedly revolutionized by the new methods developed and disseminated by government agencies of its Department of Agriculture." The innovation phenomenon would have an institutional character $[20,21,22,23]$. In a neoSchumpeterian approach to technological diffusion, diffusion conceived as an integral part of the innovation process is central.

Rosenberg [4] points out conditioning factors of the innovation process, which involve suppliers and users, such as improvement of inventions, development of technical skills, development of skills in the manufacture of machines, institutional context, among others, "may hinder or facilitate the process of diffusion of innovations".

In the area of innovation classic and contemporary authors, among them, Schumpeter, Nelson, Freeman, Porter, Mazzucato and Tigre identified different elements affecting innovation in different times and places. In the vitivinicultural sector in the São Francisco Valley, the cooperation and research of Embrapa Semiárido will be identified in the table grapes, fine wines and grape segment as catalysts for strengthening the local industry.

The purpose of the work is to situate the role of the Brazilian Agricultural Research Corporation (Embrapa) in the wine industry in the São Francisco Valley. Indicating the possibility of verifying the hypothesis of direct interaction with producers and correlation with the competitiveness of products launched on the market. 
The problem concerns the hypothesis of framing agricultural research $[24,25]$ institutions in local wine production systems. Through research carried out by Embrapa Semiárido, EMBRAPA's local unit in the São Francisco Valley wine region, in northeastern Brazil. Considering the diffusion of knowledge and technologies made by Embrapa and the resulting innovations in the Local Production System under analysis.

\section{METHODOLOGY}

This study is a qualitative research approach, in the form of a case study. The subjects are linked to the management and industrial production of wines in the São Francisco valley, in the state of Bahia and Pernambuco. Participants are oenologists, managers and researchers who work in the region's wine production environment.

The concept adopted is based on a constructivist perspective and aims to capture the understanding of the participants in the construction of the local production system in the region. We intend to interpret the meaning of the individual and organizational experiences of these actors in the region. [26]. The research process privileges the meanings and data shared by the participants.

The strategy proposed in conducting the investigation as a Case Study aimed to explore in depth the productive process in the sector and the problem of the diffusion of knowledge and technologies of Embrapa Semiárido and the consequent innovations in the Local Production System in the wine region of the São Francisco Valley. A set of data is used through interviews, documents and texts.

In this exploratory approach to the wine context in the region, we seek to elaborate an analysis of the role of the Brazilian Agricultural Research Corporation in the local wine production system in the Valley of San Francisco based on testimonials and data, seeking the trajectory of the evolution of the wine industry in the region.

The data sources are the local participants in the production system, researchers, government, published documents and reports released by the sources above. Data collection procedures are interviews with open questions conducted with participants. These direct materials are added to publications in the EMBRAPA database. Using interview, observation and consent forms for data collection.

The organization of the collected data is followed by the analysis of the information provided by the participants. With the perspectives found and the data were organized after the transcriptions and coded according to the theme located in the interviews. The related themes can thus generate an interpretation of the meanings of the descriptions obtained based on the participants.

\section{RESULTS AND DISCUSSION}

We discovered with a research a positive link between the performance of several actors in the wine region. Among Embrapa Semiárido researchers, agents of the federal government, teaching and research institutions, such as Universities, industrial companies in the wine sector. This connection may have resulted in the region's economic growth and the interest of local companies. These connections 
occur through the diffusion of technologies and knowledge in the field of agricultural research for vitiviniculture.

The interactions in the production system and the decisions in the context of the system according to the data can have an impact on regional performance in the area of wine production.

In the São Francisco Valley, the area with vines increased by $26.75 \%$, in Pernambuco. The production was 390.3 thousand tons of grapes in 2017, an increase of $60.64 \%$, compared to the previous year. In Bahia, which in the years 2005 to 2007 had exceeded 100 thousand tons of grape production, in 2017 it produced only 51.09 thousand, according to data from Comunicado-Técnico-207.

Studies published by EMBRAPA and its researchers through the institution's publications have reflected on agricultural research, a science technology and innovation policy linked to agriculture and agribusiness. Understand in the study that the Local Production System in San Francisco is circumscribed in terms of its production using innovation.

According to Mendes [4] the "agricultural research system integrates or the innovation system in agriculture. Agricultural research is one of the instruments of the Brazilian government's agricultural policy" in context of the National Agricultural Research System and under the coordination of the Brazilian Agricultural Research Corporation.

According to Sampaio et al [27] "An innovation and, especially, a technology, were considered as the differential factor of participation between companies and even countries" Based on studies by Lundvall and Freeman, as an approach to the term innovation, an innovation system is presented as a set of institutions that collaborate for the development of the "capacity for innovation and learning of a segment, sector, locality, region or even country".

The dissemination and use of knowledge are "elements and relationships that interact in the production process". [27]. In this way, in a company, innovation processes are "generated and sustained by its relations with other companies and organizations".

This resource found in the study is innovative, while a "systemic and interactive phenomenon, includes different types of cooperation and interaction" [27]. The insertion of public and private research-oriented institutions is central, as found in the role of EMBRAPA in the productive system of the studied São Francisco valley.

Vargas [28] presents elements that characterize Local Productive and Innovative Systems. No study has found a diversity of economic, political and social activities and actors in the region; an outstanding territorial dimension; an importance associated with tacit knowledge; a real and potential existence of innovation and interactive learning processes; and, as forms of governance inherent in the relationships between different segments of actors.

\section{CONCLUSION}

The study points to the gap on the role played by research institutions in the interaction with the agroindustrial productive segment in wine, particularly in the Local 
Production System in the wine region of the São Francisco Valley. Embrapa Semiárido's knowledge and technology diffusion processes have the potential for dynamic articulation with innovations in the Local Productive System in the São Francisco Valley wine region.

The structuring of government research activity in the region would favor a process of development and industrial production of wines on site. Through the development of research, innovation in the place of wine production was related to the scientific resource and to the processes of diffusion of knowledge and technologies led by Embrapa.

The Wine Production Zone in the São Francisco Valley is understood as a Local Production System permeated by EMBRAPA's activity. In this system, a set of actors from the research organization acted with a focus on technological innovation, generation and diffusion of applied knowledge, aiming at modernization, competitiveness and productive development in the region.

Other studies carried out on the role of public agricultural research organizations on innovation in local agricultural production systems can broaden the understanding of the impact of knowledge and technologies generated on the most modern agroindustrial productive sectors. Future studies can better situate the impact of research on industrial production in the context of agribusiness.

In the specific context of the São Francisco Valley region, the identified interactions allow us to situate the positive role of scientific and technological research and development within the scope of viticulture activity through the results of agricultural research disseminated by the institution.

\section{Acknowledgments}

We are grateful for the financial support of the Bahia State Research Foundation (FAPESB) for the research grant awarded (2116/2019).

\section{REFERENCES}

1EMPRESA BRASILEIRA DE PESQUISA AGROPECUÁRIA (EMBRAPA). Portal Embrapa. Available in: <https://www.embrapa.br/>. Accessed in: 10 jul.2019.

${ }^{2}$ PROTAS, José Fernando da Silva. Vitivinicultura brasileira : panorama setorial de 2010. Brasília, DF: SEBRAE; Bento Gonçalves: IBRAVIN: Embrapa Uva e Vinho, 2011.

${ }^{3}$ BERGER, J. ; NAKANE, M. T. ; SAMPAIO, R. R. Embrapa e disseminação da Informação. In: V Workshop de pesquisa tecnologia e inovação (PTI), 2015, Salvador. Anais do V Workshop de Pesquisa Tecnologia e Inovação (PTI). Salvador: Senai Cimatec, 2015. p. 315-322.

${ }^{4}$ MENDES, Cássia Isabel Costa. Transferência de tecnologia da Embrapa: rumo à inovação. 2015. 386 p. Tese (doutorado) - Universidade Estadual de Campinas, Instituto de Economia, Campinas, SP. Available 
in:<http://www.repositorio.unicamp.br/handle/REPOSIP/286446>. Accessed in: 10 jul.2019.

${ }^{5}$ FIGUEIREDO, Paulo N. New challenges for public research organisations in agricultural innovation in developing economies: Evidence from Embrapa in Brazil's soybean industry. The Quarterly Review of Economics and Finance, v. 62, p. 2132, 2016.

${ }^{6}$ CIARLI, Tommaso; RÀFOLS, Ismael. The relation between research priorities and societal demands: The case of rice. Research Policy, v. 48, n. 4, p. 949-967, 2019.

7 EASTWOOD, Callum; KLERKX, Laurens; NETTLE, Ruth. Dynamics and distribution of public and private research and extension roles for technological innovation and diffusion: Case studies of the implementation and adaptation of precision farming technologies. Journal of Rural Studies, v. 49, p. 1-12, 2017.

${ }^{8}$ HUNT, Warren et al. Recommendations arising from an analysis of changes to the Australian agricultural research, development and extension system. Food Policy, v. 44, p. 129-141, 2014.

${ }^{9}$ LIRBÓRIO, Lúcia Ferreira. Interação instituto de pesquisa - empresas:

contribuições da Embrapa Semiárido para o desenvolvimento da fruticultura irrigada no Vale do Submédio São Francisco. Recife, 2012. 186 folhas Dissertação (mestrado) - Universidade Federal de Pernambuco. CFCH. Programa de PósGraduação em Geografia, 2012.

10 SA, I. B.; SILVA, P. C. G. da. (Ed.). Semiárido brasileiro: pesquisa, desenvolvimento e inovação. Petrolina: Embrapa Semiárido, 2010.

${ }^{11}$ BARNES, Andrew P. Towards a framework for justifying public agricultural R\&D: the example of UK agricultural research policy. Research Policy, v. 30, n. 4, p. 663672, 2001.

12 THORNTON, Philip K. et al. Responding to global change: A theory of change approach to making agricultural research for development outcome-based.

Agricultural Systems, v. 152, p. 145-153, 2017.

13 NEHRING, Ryan. Yield of dreams: Marching west and the politics of scientific knowledge in the Brazilian Agricultural Research Corporation (Embrapa). Geoforum, v. 77, p. 206-217, 2016.

${ }^{14}$ EMBRAPA SEMIÁRIDO. Centro de Pesquisa Agropecuária do Trópico SemiÁrido. Available in: <https://www.embrapa.br/semiarido> Accessed in: 10 jul. 2019.

15 SUZIGAN, W.; FURTADO, João ; GARCIA, Renato de Castro . Identificação, Mapeamento e Caracterização Estrutural de Arranjos Produtivos Locais no Brasil. Campinas: IPE/DISET, 2006.

${ }^{16}$ SUZIGAN, Wilson; GARCIA, Renato; FURTADO, João. Clusters ou sistemas locais de produção e inovação: identificação, caracterização e medidas de apoio. São Paulo: IEDI, p. 12-19, 2002. 
17 SAMPAIO, R. R.; ALBUQUERQUE, J. C. M. Difusão do Conhecimento e Inovação em Sistemas Locais de Produção: Uma modelagem baseada na Dinâmica de Sistemas. In: XXXVII EnANPAD, 2013, Rio de Janeiro. Anais do XXXVII EnANPAD, 2013.

18 DE-CARLI, Eduardo et al. Characterization on the patents deposits from Brazil's Public Research Institutes from 2004 to 2013. Revista de Administração e Inovação, v. 14, n. 2, p. 168-177, 2017.

19 JUNIOR, Admir Antonio Betarelli et al. Research and development, productive structure and economic effects: Assessing the role of public financing in Brazil.

Economic Modelling, v. 90, p. 235-253, 2020.

20 MATT, Mireille et al. Opening the black box of impact-ldeal-type impact pathways in a public agricultural research organization. Research Policy, v. 46, n. 1, p. 207$218,2017$.

${ }^{21}$ FAURE, Guy et al. How different agricultural research models contribute to impacts: Evidence from 13 case studies in developing countries. Agricultural Systems, v. 165, p. 128-136, 2018.

22 GAUNAND, Ariane et al. How does public agricultural research impact society? A characterization of various patterns. Research Policy, v. 44, n. 4, p. 849-861, 2015.

${ }^{23}$ MATERIA, Valentina Cristiana; PASCUCCI, Stefano; KOLYMPIRIS, C. Understanding the selection processes of public research projects in agriculture: The role of scientific merit. Food Policy, v. 56, p. 87-99, 2015.

${ }^{24}$ BRAUNSCHWEIG, Thomas; JANSSEN, Willem; RIEDER, Peter. Identifying criteria for public agricultural research decisions. Research Policy, v. 30, n. 5, p. 725-734, 2001.

${ }^{25}$ E SOUZA, Geraldo da Silva; GOMES, Eliane Gonçalves. A Performance Measure to Support Decision-Making in Agricultural Research Centers in Brazil. Procedia Computer Science, v. 55, p. 405-414, 2015.

${ }^{26}$ CRESWELL, John W. Projeto de pesquisa: métodos qualitativo, quantitativo e misto. 3 ed. Porto Alegre: ARTMED, 2010.

27 SAMPAIO, R. R.; ALBUQUERQUE, J. C. M. ; LACERDA, R. V. . Abordagem de Sistemas de Inovação na Perspectiva da Criação e Difusão do Conhecimento nas Organizações. International Journal of Knowledge Engineering and Management, v. 5, p. 49-67, 2016.

28 VARGAS, M. A. Aspectos conceituais e metodológicos na análise de arranjos e sistemas produtivos e inovativos locais. Programa de Pesquisa Micro e Pequenas Empresas em Arranjos Produtivos Locais no Brasil. Rio de Janeiro: IE/UFRJ. 2004. 